\title{
"Tutkimuksen tekeminen työn rinnalla on ollut itseni kehittämistä mutta samalla vaikuttamisen keino"
}

\author{
Väitöstutkimuksessaan Johanna Vilppola, 45, sai selville, \\ että kuntoutujan oma kokemus toimijuudesta ohitetaan, \\ kun arvioidaan tämän työ- ja opiskelukykyä.
}

MINUSTA TULI TUTKIJA, koska tutkijuus oli jo pitkään ollut osa ammatillista identiteettiäni. Siihen kuuluu tutkimuksen lisäksi yritysten kouluttamista, työnohjauksia, kehittämispäivien pitämistä ja valmennuksia. Toimin työhyvinvoinnin ja kriisityön asiantuntijana Treili Oy:ssä.

Tarinani tutkimuksen parissa sai alkunsa perhetilanteestani jo 15 vuotta sitten. Pohdin pienten lasten äitinä, mitä omaa voisin tehdä aluksi kotiäitiyden ja myöhemmin työn ja perheen yhdistämisen rinnalla. Lähdin avoimeen yliopistoon opiskelemaan monenlaista: kasvatustiedettä, erityispedagogiikkaa, henkilöstöjohtamista ja psykologiaa. Valmistuin Tampereen yliopistosta kasvatustieteen maisteriksi vuonna 2014. Lasten kasvettua haluni vaikuttaa yhteiskunnallisesti kasvoi, ja aloitin tohtoriopinnot Turun yliopistossa.

Olen koko ajan ollut kokopäivätöissä psykiatrisena sairaanhoitajana, ammatillisena opettajana, kouluttajana tai työnohjaajana. Tutkimuksen tekeminen työn rinnalla on pääasiallisesti ollut itseni kehittämistä, mutta samalla se on hyödyllinen keino vaikuttaa organisaatiotasoilla ja laajemminkin kansallisesti sekä kansainvälisesti.

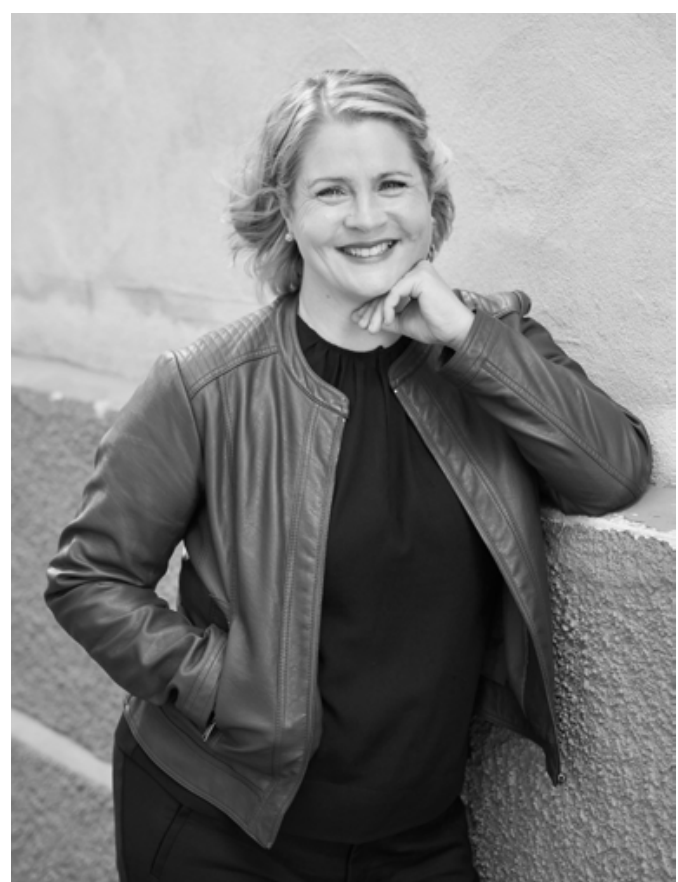

Johanna Vilppola arvostaa monitieteisyyttä. Väitöstutkimuksessaan hän yhdisti aikuiskasvatuksen muun muassa sosiologiaan ja lääketieteeseen. 


\section{TUTKIJAN YHTEISKUNNALLINEN VASTUU ON ANTAA ARVOA MUILLE TUTKIJOILLE JA ERI ALOJEN TOIMIJOILLE.}

JOS EN TUTKISI, lukisin romaaneja. Olen tehnyt tutkimusta vain silloin, kun olen voinut hyvin. Elämän tuomien murheiden tai kuormituksen aikana olen pitänyt tutkimuksesta taukoa. Tutkimuksen tekeminen energisenä ja hyväntuulisena on edistänyt tutkimusta ja auttanut näkemään monipuolisesti eri vaihtoehtoja. Toki kirjallisuutta olen saattanut lukea vähäenergisempinäkin aikoina.

AIKUISKASVATUSTIEDETTÄ TARVITAAN yhteiskunnassa, koska sillä on laajat mahdollisuudet niin itsenäisenä tieteenä kuin monitieteisessä yhteistyössä. Tieteiden välinen keskustelevuus on tärkeää, jotta emme sulje pois muita nostaessamme itseämme, omaa tiedettämme tai näkökulmaamme.

Omassa väitöskirjassani oli läsnä aikuiskasvatuksen lisäksi ainakin sosiologiaa, hoitotiedettä, läketiedettä, erityispedagogiikkaa ja politiikan tutkimusta. Tutkijan yhteiskunnallinen vastuu on antaa arvoa muille tutkijoille ja yhteiskunnan eri alojen toimijoille - huolimatta siitä, tutkivatko, ajattelevatko tai ovatko he kiinnostuneita samoista asioista kuin itse on.

Selvitin tammikuussa tarkastetussa kasvatustieteen väitöskirjassani mielenterveyskuntoutujien elämänkerrontojen avulla heidän elämänsä rakentumisen teemoja sekä koulutuksen ja työn asemaa heidän elämässään. Koulutus- ja työtoimijuusnäkökulma on tärkeä, koska sairauspoissaolot ja työkyvyttömyyseläkkeet ovat lisääntyneet. Tutkimukseni perusteella väitän, että mielenterveyskuntoutujan työ- ja opiskelukykyä arvioitaessa henkilön oma kokemus toimijuudesta on jäänyt muiden tekijöiden varjoon. Väitöskirjassani laadin kuntoutujille ja heidän kanssaan työskenteleville ammattilaisille työkalun, joka tukee oman koulutus- ja työtoimijuuden arviointia.

Innostun monista eri näkökulmista ja lähestymistavoista. En halua nostaa esiin yhtä esikuvaa tai teoriaa vaan pidän tärkeämpänä kokonaisuuksia.
SEURAAVAKSI AION kirjoittaa muutamia artikkeleita väitöstutkimukseni pohjalta. Minua kiinnostaa myös kovasti kriisityön tutkiminen. Käytännön osaamiseni ja ymmärrykseni yhdistäminen tutkimukseen on minulle tärkeää.

KOLLEGOILTANI SAAN monenlaista tukea. Ammattitutkijoiden kanssa kirjoittaminen on erityisen opettavaista. Suunnitteilla on esimerkiksi artikkeli tyyppitarinoiden tutkimisesta toisen ohjaajani, Markku Vanttajan kanssa. Kaikenlainen yhteistyö käytännön työn ja tutkimuksen välimaastossa tuntuu hedelmälliseltä. Kirjoitin esimerkiksi hiljattain työnohjaajien ammattilehteen Osviittaan artikkelin lastensuojeluyksiköiden työnohjauksesta.

KUN EN TUTKI, vietän aikaa perheeni kanssa. Kahden aikuisen lapsen ja yhden teini-ikäisen elämien rinnalla kulkeminen ja miehen kanssa elämän jakaminen on parasta palautumista - luotettavia sukulaisia ja ystäviäni unohtamatta. Rentoudun lisäksi islanninhevosten ja saunomisen parissa. Opettelen neulomaan villasukkia ja haaveilen lukuisten romaanien lukemisesta. Rentoutuneena mieleeni saattaa putkahtaa oivallinen idea tutkimukseen. Tavallaan tutkimustyö on aina mukana.

\section{Klassikko, johon palaan}

Aate- ja oppihistorian professori Petteri Pietikäisen teos Hulluuden historia (Gaudeamus 2013) auttaa ymmärtämään, miksi mielenterveyden haasteet ja koulutus- ja työtoimijuus ovat mahtuneet samaan virkkeeseen vasta muutaman vuosikymmenen ajan.

\section{Lisää aiheesta}

Vilppola, J. (2021) Toimijat, taistelijat, tipahtaneet. Koulutus- ja työtoimijuus mielenterveyskuntoutujien elämänkerronnoissa. Väitöskirja. Turun yliopisto. https:// www.utupub.fi/handle/10024/150845 